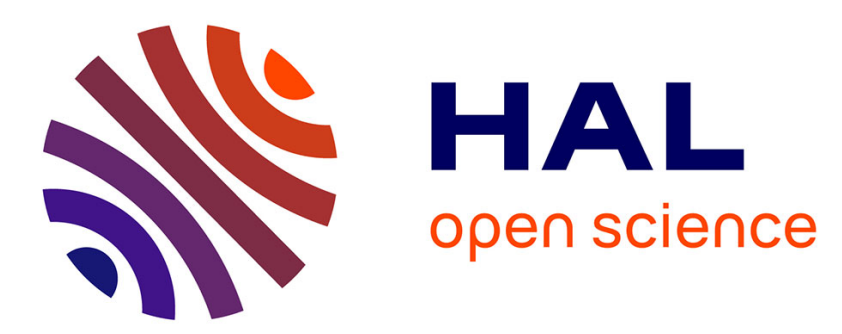

\title{
Tanned or sunburned: How excessive light triggers plant cell death
}

Stefano d'Alessandro, Inès Beaugelin, Michel Havaux

\section{To cite this version:}

Stefano d'Alessandro, Inès Beaugelin, Michel Havaux. Tanned or sunburned: How excessive light triggers plant cell death. Molecular Plant, 2020, 13 (11), pp.1545-1555. 10.1016/j.molp.2020.09.023 . hal-03303923

\section{HAL Id: hal-03303923 \\ https://hal-amu.archives-ouvertes.fr/hal-03303923}

Submitted on 16 Sep 2021

HAL is a multi-disciplinary open access archive for the deposit and dissemination of scientific research documents, whether they are published or not. The documents may come from teaching and research institutions in France or abroad, or from public or private research centers.
L'archive ouverte pluridisciplinaire HAL, est destinée au dépôt et à la diffusion de documents scientifiques de niveau recherche, publiés ou non, émanant des établissements d'enseignement et de recherche français ou étrangers, des laboratoires publics ou privés. 
1 Tanned or Sunburned: How Excessive Light Triggers Plant Cell Death

2

3 Stefano D'Alessandro ${ }^{1,3}$, Inès Beaugelin ${ }^{2}$ and Michel Havaux ${ }^{1,3}$

4

5

6

8

9

10

11

12

13 of Aix Marseille, F-13108 Saint-Paul-lez-Durance, France

${ }^{3}$ Co-senior authors

(1)

Running Title: Plant cell death induced by excessive light 2

Corresponding authors:

Michel Havaux, Tel: +33 44225 7476, michel.havaux@cea.fr

Stefano D’Alessandro, stefano.dalessandro.phd@gmail.com 16

\section{Short Summary} 2 death, stress response.

${ }^{1}$ Aix-Marseille University, CEA, CNRS, UMR7265, BIAM, Institute of Biosciences and Biotechnologies

${ }^{2}$ Singapore-CEA Alliance for Research in Circular Economy (SCARCE), School of Chemical and Biomedical Engineering, 62 Nanyang Drive, Singapore 637459, Republic of Singapore

Capturing light intensities exceeding the capacity of photosynthesis can lead to cell death in plant leaves. In this review, we summarize recent findings on the mechanisms mediating light-induced cell death, highlighting the role of reactive carbonyl species, of the endoplasmic reticulum and of phytohormones in the adoption of phototolerance versus cell death pathways.

Keywords: Arabidopsis, photosynthesis, excessive light, photooxidative stress, carotenoid, plant cell 
Plants often encounter light intensities exceeding the capacity of photosynthesis (excessive light) mainly due to biotic and abiotic factors, which lower $\mathrm{CO}_{2}$ fixation and reduce light energy sinks. Under excessive light, the photosynthetic electron transport chain generates damaging molecules hence leading to photooxidative stress and eventually to cell death. In this review, we summarize the mechanisms linking excessive absorption of light energy in the chloroplasts to programmed cell 39 death in plant leaves. We highlight the importance of reactive carbonyl species generated by lipid photooxidation, their detoxification, and the integrating role of the endoplasmic reticulum in the

41 adoption of phototolerance or cell death pathways. Finally, we invite the scientific community to standardize the conditions of excessive light treatments. 


\section{Abbreviations}

PFD, Photon Flux Density; ROS, Reactive Oxygen Species; RWC, Relative Water Content; OEC, Oxygen Evolving Complex; PCD, Programmed Cell Death; RCS, Reactive Carbonyl Species; HNE, 4Hydroxy-2-nonenal; NPQ, Non-Photochemical Quenching; JA, Jasmonic acid; JA-lle, JasmonoylIsoleucine; SA, Salicylic acid; OXI1, OXIDATIVE STRESS INDUCIBLE 1; EX1, EXECUTER 1; ER, Endoplasmic Reticulum; UPR, Unfolded Protein Response; $A B A$, abscisic acid; ${ }^{1} \mathrm{O}_{2}$, singlet oxygen.

\section{Introduction}

Plants often encounter light intensities that exceed the needs of photosynthesis (Ort, 2001). Light energy that is not used to assimilate $\mathrm{CO}_{2}$ or dissipated can be considered to be in excess and leads to a depression of photosynthetic efficiency, especially at PSII (Kato et al., 2003; Murata et al., 2007). Excessive light occurs mainly in response to biotic and abiotic factors, such as drought, heat or pests, and lowers the capacity of light energy sinks, first and foremost $\mathrm{CO}_{2}$ fixation. The excess electrons and excitation energy can be transferred to molecular oxygen, generating biologically damaging molecules such as reactive oxygen species (ROS), peroxides and radicals, hence leading to photooxidative stress that can ultimately lead to cell death (Apel and Hirt, 2004; Li et al., 2009).

\section{High light under different conditions induces different responses}

The real condition of excessive light, which is dependent on photosynthetic activity and can also occur at relatively low light intensities, is often confused with 'high light' treatment. Drought stress, nutrient starvation or pathogens can lead to the same state of overexcitation of the photosystems, without the imposition of high light (Garai and Tripathy, 2018; Wang et al., 2018; Pérez-Bueno et al., 2019). Likewise, by playing with the $\mathrm{CO}_{2}$ and $\mathrm{O}_{2}$ composition of the gas phase, Montané et al. (1998) generated the same excitation pressure on the photosystems at different photon flux densities (PFDs) (Montané et al., 1998). In addition, the intensity of sunlight that leaves receive under natural conditions often fluctuates, because of clouds and intermittent shading by other leaves or plants. This "fluctuating light" can be very damaging to the photosynthetic machinery, particularly PSI, even at relatively low PFDs (Kono et al., 2014; Yamori et al., 2016).

PFDs used in the literature to induce excessive light range from 500 to $2000 \mu \mathrm{mol}$ photons $\mathrm{m}^{-2} \mathrm{~s}^{-1}$. These treatments can also increase leaf temperature and, unless air temperature is controlled, will 
impose a double condition of excessive light and heat stress. Lack of leaf temperature control in experimental protocols increases interlaboratory data variability and makes comparison between different studies more difficult.

Even when leaf temperature is controlled by lowering air temperature, different setups have been adopted, such as $600 \mu \mathrm{mol}$ photons $\mathrm{m}^{-2} \mathrm{~s}^{-1}$ PFD at $23^{\circ} \mathrm{C}$ air temperature (Balfagón et al., 2019), 1500 $\mu \mathrm{mol}$ photons $\mathrm{m}^{-2} \mathrm{~s}^{-1}$ at $7^{\circ} \mathrm{C}$ (Ramel et al., 2012; D'Alessandro et al., 2018), $1200 \mu \mathrm{mol}$ photons $\mathrm{m}^{-2}$ $\mathrm{s}^{-1}$ at $18^{\circ} \mathrm{C}$ (Lv et al., 2015), $1200 \mu \mathrm{mol}$ photons $\mathrm{m}^{-2} \mathrm{~s}^{-1}$ at $11.5^{\circ} \mathrm{C}$ (Huang et al., 2019) or $2000 \mu \mathrm{mol}$ photons $\mathrm{m}^{-2} \mathrm{~s}^{-1}$ at $4^{\circ} \mathrm{C}$ (Mattila et al., 2019). These studies show that leaf temperature remains at standard levels $\left(20-22^{\circ} \mathrm{C}\right)$ when exposed to $1500 \mu \mathrm{mol}$ photons $\mathrm{m}^{-2} \mathrm{~s}^{-1}$ at $7^{\circ} \mathrm{C}$ or $1200 \mu \mathrm{mol}$ photons $\mathrm{m}^{-2} \mathrm{~s}^{-1}$ at $11.5^{\circ} \mathrm{C}$. However, leaf temperature increases by $4^{\circ} \mathrm{C}$ (from $23^{\circ} \mathrm{C}$ to $27^{\circ} \mathrm{C}$ ) when exposed to $600 \mu \mathrm{mol}$ photons $\mathrm{m}^{-2} \mathrm{~s}^{-1}$ or $13^{\circ} \mathrm{C}$ (from $22^{\circ} \mathrm{C}$ to $35^{\circ} \mathrm{C}$ ) at $1200 \mu \mathrm{mol}$ photons $\mathrm{m}^{-2} \mathrm{~s}^{-1}$ if air temperature is not lowered.

Several studies have indicated that there can be significant overlap between high light and heat stress responses when air temperature is maintained at normal growth temperature. Balfagón et al. (2019) compared a 7-h high light treatment $(\mathrm{HL})$ with a heat shock treatment $\left(\mathrm{HS}, 42^{\circ} \mathrm{C}\right)$ and the combination of both (Balfagón et al., 2019). The $\mathrm{HL}$ treatment caused a $4^{\circ} \mathrm{C}$ increase in leaf temperature, from $23^{\circ} \mathrm{C}$ to $27^{\circ} \mathrm{C}$, the $\mathrm{HS}$ treatment increased leaf temperature by around $10^{\circ} \mathrm{C}$, from $23^{\circ} \mathrm{C}$ to $33^{\circ} \mathrm{C}$, and the combined stresses increased leaf temperature by around $10-12^{\circ} \mathrm{C}$. Analysis of transcriptomes showed an astonishing resemblance between $\mathrm{HL}$ (at $23^{\circ} \mathrm{C}$ air temperature) and HS, with a large fraction of the modified genes being common between the two stresses, corresponding to $58 \%$ (4439) of $\mathrm{HL}$ alone. This result suggests that performing $\mathrm{HL}$ experiments at $23^{\circ} \mathrm{C}$ air temperature causes a response partially overlapping with $\mathrm{HS}$, likely due to the increase in leaf temperature. While the combination of HS and HL was equally similar to HS and to HL (64\% overlap) on a transcriptional level, other experiments indicated a dominance of HS during HL stress. In fact, while $\mathrm{HL}$ performed at $23^{\circ} \mathrm{C}$ caused stomatal closure, $\mathrm{HS}$ and $\mathrm{HL}+\mathrm{HS}$ induced stomatal opening. Relative water content (RWC) was unperturbed by HL but reduced from $75 \%$ to $60 \%$ by HS and $\mathrm{HS}+\mathrm{HL}$. The number of starch granules diminished in $\mathrm{HL}$ but increased under $\mathrm{HS}$ and $\mathrm{HS}+\mathrm{HL}$. $\mathrm{H}_{2} \mathrm{O}_{2}$ production increased in $\mathrm{HS}$ and $\mathrm{HS}+\mathrm{HL}$-treated plants but did not in HL-treated plants, in agreement with previous analyses of pure excess light (D'Alessandro et al., 2018). Similar results 
were observed in another study when analyzing the systemic response to $\mathrm{HL}$, $\mathrm{HS}$ and the combination of both stresses (Zandalinas et al., 2020).

\section{The lipid problem in excessive light}

ROS production under stress conditions initially elicits a signaling cascade and, if sufficient quantities are produced to overwhelm defense mechanisms, also leads to cellular damage. Singlet oxygen $\left({ }^{1} \mathrm{O}_{2}\right)$ is a very harmful and likely the major ROS produced under excessive light (Triantaphylidès et al., 2008; Ramel et al., 2012; D’Alessandro and Havaux, 2019; Khorobrykh et al., 2020). In fact, a ${ }^{1} \mathrm{O}_{2}$ mediated transcriptional response can be detected after a 24-h high light treatment at controlled air temperature, while marker genes for $\mathrm{H}_{2} \mathrm{O}_{2}$ are not induced (Shumbe et al., 2017). This result is in line with the increased biosynthesis of $\mathrm{H}_{2} \mathrm{O}_{2}$ and the induction of $A P X 2$ only when high light conditions are combined with heat stress (Smirnoff and Arnaud, 2019; Balfagón et al., 2019; Huang et al., 2019). Notably, the $\mathrm{O}_{2}$-evolving-complex (OEC) proteins are particularly susceptible to heat stress (Berry and Bjorkman, 1980; Weis and Berry, 1988; Havaux, 1993), and OEC-depleted PSII predominantly generates $\mathrm{H}_{2} \mathrm{O}_{2}$ (Khorobrykh et al., 2020). Only a prolonged high light stress is therefore likely to cause a combined accumulation of ${ }^{1} \mathrm{O}_{2}$ and $\mathrm{H}_{2} \mathrm{O}_{2}$ (Laloi and Havaux, 2015).

ROS, and especially ${ }^{1} \mathrm{O}_{2}$, are highly reactive towards carbon-carbon double bonds. ROS are primarily produced at the level of the photosystems in a lipid rich environment, and so oxidized lipids are one of the major products of ROS generation in response to excessive light. Fatty acids are highly unsaturated in plant leaves (Douce and Joyard, 1980) and are therefore very sensitive to oxidation (Bour et al., 2019). The major fatty acids in leaves are the polyunsaturated fatty acids linolenic acid (C18:3) and linoleic acid (C18:2) containing 3 and 2 double bonds, respectively. At the level of thylakoids, a primary site of ROS production, the ratio between unsaturated to saturated lipids is 9.4 to 1, and linolenic acid corresponds to $70 \%$ of total fatty acids (Chapman and Barber, 1986; Yalcinkaya et al., 2019). Considering Arabidopsis whole leaves, linolenic acid can represent up to 50 $\%$ of the total fatty acid content (Li-Beisson et al., 2013). Consequently, lipid peroxidation is usually a primary event associated with ROS production and oxidative stress in plants (Birtic et al., 2011). The attack of lipids by ROS generates specific peroxides, notably lipid endoperoxides specific to ${ }^{1} \mathrm{O}_{2}$, while lipid radicals and lipid peroxyl radicals are specific to reduced oxygen forms (Mano et al., 
2019b; Khorobrykh et al., 2020). In a second stage, all these molecules are transformed into lipid hydroperoxides.

High light treatment with controlled air temperature was found to be systematically associated with a lipid peroxidation signature typical of ${ }^{1} \mathrm{O}_{2}$ (Triantaphylidès et al., 2008), indicating a major role for this ROS in photooxidative degradation of plant lipids. The abundance of polyunsaturated fatty acids has been proposed to act as a sink for ROS, especially ${ }^{1} \mathrm{O}_{2}$, in chloroplasts, which could constitute a protection mechanism against propagation of oxidative stress (Mène-Saffrané et al., 2009). However, lipid peroxides are not only the signature of photooxidation but also directly contribute to signaling and toxicity.

Phytoprostanes and phytofurans are compounds derived from non-enzymatic oxidation of $\alpha$ linolenic acid in plants (Mueller, 2004; Durand et al., 2011; Collado-González et al., 2016; Galano et al., 2017) (Fig. 1). Because of their structural analogies with isoprostanes and prostanoids, these lipid derivatives may constitute a new class of bioactive plant compounds in response to oxidative stress (Mueller et al., 2008). Some phytoprostanes contain an electrophilic site, which can react and make adducts with proteins (Liebler, 2008). Typical reactions are Schiff base formation and Michael addition. Accumulation of phytoprostanes/phytofurans has been reported in various photosynthetic organisms under oxidative stress (Loeffler et al., 2005; Yonny et al., 2016; Lupette et al., 2018), potentially playing a role in plant responses to photooxidative stress.

Lipid hydroperoxides spontaneously fragment into a variety of secondary compounds that can exhibit high reactivity towards biomolecules. Reactive carbonyl species (RCS) are the $\alpha, \beta$ unsaturated aldehydes and ketones derived from lipid peroxides, which can further hinder the physiological functioning of macromolecules and induce cell death (Farmer and Mueller, 2013; Mano et al., 2019b). Some of these molecules, such as (E)-2-hexenal, have been studied as Green Leaf Volatiles and previously reviewed (Ameye et al., 2018). RCS, such as hydroxynonenal (HNE), acrolein or malondialdehyde (Fig. 1), are electrophiles and hence can react with nucleophilic groups in biomolecules to make covalent bonds (Mano, 2012; Mano et al., 2019b). In this way RCS may change protein conformation or alter protein function under stress conditions, consequently affecting metabolic or signaling processes (Biswas and Mano, 2016; Yalcinkaya et al., 2019). 


\section{Promiscuous, broad-spectrum detoxification of lipid peroxidation by-products}

Reactive molecules, both of endogenous or exogenous origin, may constitute a hazard for the cell and lead to cell death. Plants have evolved a detoxification mechanism that can neutralize these dangers. As this mechanism was discovered when studying the response to herbicides, it was called the 'xenobiotic response' (Sandermann, 1992; Kreuz et al., 1996; Riechers et al., 2010). This process is organized in three phases, modification, conjugation and compartmentalization, and enzyme families participating in each phase of the xenobiotic response are reported in Fig. 2.

Enzymes of the modification phase are active towards RCS and catalyze their conversion into less dangerous molecules (Mano et al., 2019b). RCS detoxification can occur through different enzymatic reactions: (i) reduction of the $\alpha, \beta$-unsaturated bond in an RCS molecule using $\mathrm{NAD}(\mathrm{P}) \mathrm{H}$ as the electron donor, by alkenal reductase (AER) and alkenal/one oxidoreductase (AOR); (ii) reduction of a carbonyl moiety to an alcohol using $\mathrm{NAD}(\mathrm{P}) \mathrm{H}$, catalyzed with aldo-keto reductase (AKR); (iii) oxidation of an aldehyde to a carboxylic acid using $\mathrm{NAD}^{+}$as the electron acceptor, catalyzed by aldehyde dehydrogenase (ALDH); (iv) oxidation of an aldehyde using $\mathrm{O}_{2}$ as the electron acceptor catalyzed by aldehyde oxidase (AO) (Mano et al., 2002; Stiti et al., 2011; Yamauchi et al., 2011; Yamauchi et al., 2012; SAITO et al., 2013; Srivastava et al., 2017). In addition, formation of a glutathione or glucoside adduct of RCS can be catalyzed by enzymes of the conjugation phase (i.e. glutathione transferase (GST)) (Mano et al., 2017; Mano et al., 2019a).

Several of these enzymes are induced under stress conditions, in accord with the overproduction of RCS, and plants overexpressing alkenal reductases, aldo-keto reductases and aldehyde dehydrogenases are usually more tolerant to stress conditions, as reviewed in Mano et al. (2019). In addition, we have recently reported a pathway controlling acclimation to excessive light mediated by the induction of RCS detoxification by the apocarotenoid $\beta$-cyclocitral (D'Alessandro et al., 2018; D’Alessandro and Havaux, 2019). Phytoprostanes and phytofurans may also require the induction of a detoxification response to limit their effects in vivo and the rapid disappearance of phytoprostanoids in tobacco cells is consistent with this idea (Loeffler et al., 2005).

Enzymes of the modification phase are usually associated with biosynthetic pathways for secondary metabolites (Cytochrome P450 oxidases, Short Chain Dehydrogenases/Reductases, ...). At the same time, part of these large families of enzymes was identified in the response to xenobiotic compounds (Fode et al., 2008). It is likely that plants can adopt the less specific steps of the reactions 
that they perform in secondary metabolism to cope with hazardous molecules, in what could be considered a broad-spectrum (promiscuous) detoxification pathway. Ligand promiscuity and promiscuous detoxification are well-known processes in animal systems where the two promiscuous receptors CAR and PXR can bind to different molecules and controls the expression of several CYP450 genes (Tolson and Wang, 2010). These processes, catalyzed by the same families of enzymes as the xenobiotic response of plants, are active against endogenous toxicants and constitute the base of drug metabolism and pharmacokinetics. We therefore propose to adopt the animal systems nomenclature of promiscuous detoxification for the xenobiotic response in plants.

As promiscuous detoxification is active towards hazardous metabolites generated during photooxidation, such as RCS, this pathway represents a new level of photoprotection. Light-induced ROS generation is inevitably coupled with photosynthesis. ROS quenching and scavenging are continuous, but under stress conditions they could become insufficient compared to ROS production, leading to ROS accumulation. At this point, a first level of photoprotection, including nonphotochemical energy quenching (NPQ), cyclic electron transport, plastid terminal oxidase (PTOX) and state transition, reduces ROS production (Alric and Johnson, 2017; Roach and KriegerLiszkay, 2019). A second level of photoprotection, including ROS scavenging (by SOD and APX, for the superoxide anion radical and $\mathrm{H}_{2} \mathrm{O}_{2}$, respectively) and ROS quenching (by carotenoids, tocopherols and plastoquinones for ${ }^{1} \mathrm{O}_{2}$ ), avoids oxidation (Apel and Hirt, 2004; Krieger-Liszkay et al., 2008; Noctor et al., 2018; Filiz et al., 2019). The D1 protein of PSII, which is very susceptible to oxidation, can also be considered a component of photoprotection together with the well described D1 repair mechanism (Nath et al., 2013; Järvi et al., 2015; Yoshioka-Nishimura, 2016; Kato et al., 2018). When these photoprotective processes are insufficient, or inhibited by stress, oxidation of lipids generates RCS. Promiscuous detoxification can metabolize the hazardous reactive molecules to protect the cell (Fig. 3) which, under certain conditions, can trigger programmed cell death (PCD) (Biswas and Mano, 2016).

\section{From RCS to PCD}

${ }^{1} \mathrm{O}_{2}$-derived peroxidation of lipids, proteins and nucleic acids has been observed in treatments with photosensitizers (methylene blue or rose Bengal) and in Arabidopsis mutant lines overproducing ${ }^{1} \mathrm{O}_{2}$ such as flu and ch1 (Triantaphylidès et al., 2008; Shao et al., 2013; Laloi and Havaux, 2015). ch1 showed increased lipid peroxidation and photooxidative damage under excess light conditions, 
234 whereas ${ }^{1} \mathrm{O}_{2}$ is generated under non-photoinhibitory conditions in flu (Wagner et al., 2004; Ramel 235 et al., 2013a). In both ch1 and flu, ${ }^{1} \mathrm{O}_{2}$-induced cell death was dependent on signaling proteins, 236 OXIDATIVE STRESS INDUCIBLE 1 (OXI1) (in ch1 and in the wild type), EXECUTER1 (EX1) or SAFE1 (in $237 \mathrm{flu}$ ), indicating the involvement of a signaling process leading to cell death (Shumbe et al., 2016; 238 Dogra et al., 2019; Beaugelin et al., 2019; Wang et al., 2020). The EX1 protein is located in the grana 239 margins of the thylakoids (Wang et al., 2016; Dogra et al., 2018; Dogra and Kim, 2020), relatively 240 distant from the main ${ }^{1} \mathrm{O}_{2}$ source under excessive light, the PSII reaction centers in the grana core 241 (D'Alessandro and Havaux, 2019). EX1 can sense ${ }^{1} \mathrm{O}_{2}$ produced from free chlorophylls associated 242 with the PSII repair process or released during non-photoinhibitory stress, through oxidative post243 translational modification and proteolysis by the protease FtsH2 (Wang et al., 2016; Dogra et al., 244 2019). Following those modifications, EX1 can induce PCD. However, PCD in WT and ch1 leaves 245 under high PFDs at controlled temperature is independent of EX1 (Ramel et al., 2013a; Shumbe et 246 al., 2016), indicating the existence of at least two ${ }^{1} \mathrm{O}_{2}$ signaling pathways leading to cell death.

247 Prolonged exposure to extreme light conditions would result in an increased accumulation of ROS, 248 principally a combination of ${ }^{1} \mathrm{O}_{2}$ and reduced/radical $\mathrm{O} 2$ species (Laloi and Havaux, 2015; 249 Khorobrykh et al., 2020). While ${ }^{1} \mathrm{O}_{2}$ generates lipid endoperoxides, $\mathrm{O}_{2}$ radicals oxidize lipids to lipid 250 radicals and peroxyl radicals. Peroxyl radicals can react with other lipids generating a new lipid 251 radical, and again a peroxyl radical in a chain reaction (Mano et al., 2019b; Khorobrykh et al., 2020). 252 Another vicious circle has been highlighted between RCS and $\mathrm{H}_{2} \mathrm{O}_{2}$ (Biswas et al., 2020). RCS can 253 alter protein function by covalent modification (Colzani et al., 2013), and $\mathrm{H}_{2} \mathrm{O}_{2}$ scavenging enzymes 254 (catalase and ascorbate peroxidase) were observed in a study as targets of RCS (Mano et al., 2014). 255 In addition, an animal catalase has been shown to form adducts with HNE, leading to inactivation of 256 the enzyme and a compromised $\mathrm{H}_{2} \mathrm{O}_{2}$ scavenging (Bauer and Zarkovic, 2015; Biswas et al., 2020). $257 \quad \mathrm{H}_{2} \mathrm{O}_{2}$ itself can also modify the activity of enzymes of the detoxification pathway. Indeed, it was 258 recently demonstrated that, at relatively low concentrations $(0.2 \mathrm{mM}), \mathrm{H}_{2} \mathrm{O}_{2}$ hinders almost $50 \%$ of 259 the HNE-reducing activity present in BY-2 cell cultures, and this can occur within minutes (Biswas et 260 al., 2020). Thus, RCS production can result in the accumulation of $\mathrm{H}_{2} \mathrm{O}_{2}$ that could inhibit RCS 261 detoxification, hence generating a feed-forward amplification mechanism. $\mathrm{H}_{2} \mathrm{O}_{2}$ is a long-lived ROS that can travel to the nucleus and act as a signaling agent (ExpositoRodriguez et al., 2017). Nonetheless, it has been recently shown that RCS mediates $\mathrm{H}_{2} \mathrm{O}_{2}$-induced PCD by inducing caspase-3-like activity in BY-2 cell cultures (Biswas and Mano, 2016; Biswas et al., 
2020). Therefore, the overaccumulation of RCS could be a major mechanism for the induction of cell death, and a mechanism for linking photosynthetic inhibition to PCD. Consistent with this, we have observed that a 4-h pretreatment of Arabidopsis plants with HNE increased lipid peroxidation under excessive light (D'Alessandro et al., 2018).

\section{Hormonal control of excessive light-induced cell death}

A key regulator of PCD under excessive light is the AGC kinase OXI1. OXI1 mediates cell death in response to both biotic and abiotic stimuli, and it resides at the intersection of the $\mathrm{H}_{2} \mathrm{O}_{2}$ and ${ }^{1} \mathrm{O}_{2}$ signaling pathways (Shumbe et al., 2016). OXI1 is also linked to the signaling pathways of several phytohormones (Howden et al., 2011). OXI1 is required for the full activation of MAPK3 and MAPK6 to induce PCD under $\mathrm{H}_{2} \mathrm{O}_{2}$ stress (Rentel et al., 2004) and induces jasmonic acid (JA) and salicylic acid (SA) biosynthesis in high light-exposed leaves (Shumbe et al., 2016; Beaugelin et al., 2019).

There are many examples in the literature indicating a link between plant/leaf photodamage and induction of the JA pathway. For instance, the transfer of Arabidopsis plants from 80 to $800 \mu \mathrm{mol}$ $\mathrm{m}^{-2} \mathrm{~s}^{-1}$ PFD increased the concentration of JA and JA-Ile (Alsharafa et al., 2014). In apple, sun damage was also accompanied by increased concentrations of those compounds (Torres et al., 2017). Moreover, treatments of leaves with methyl-JA under excessive light enhances PSII photoinhibition and photodamage (Wierstra and Kloppstech, 2000; Ramel et al., 2013a; Savchenko et al., 2017). Photooxidative damage in the ${ }^{1} \mathrm{O}_{2}$-overproducing Arabidopsis mutant ch1 is also associated with a marked upregulation of JA biosynthesis genes and by a strong accumulation of OPDA (12-oxophytodienoic acid) and JAs (Ramel et al., 2013a). Very recently, an excessive light transcriptome of Arabidopsis plants further confirmed that plants respond to excessive light by modifying the metabolism of JA, and additionally revealed a potential role for SA and abscisic acid (ABA) (Huang et al., 2019). Together these results support the idea that JA plays an important role in response to exposure to excess light.

The role of JAs in PCD associated with plant defense against feeding insects, nematodes, fungal and bacterial pathogens is already well documented (Rentel et al., 2004; Reinbothe et al., 2009) and suggests that it may also mediate PCD under abiotic stress conditions. Indeed, JA accumulation under excess light is associated with the induction of senescence-associated factors, such as SAG12, SAG13, SEN1 and SEN4, as well as PCD inducers including MC8 and gVPE (Beaugelin et al., 2019). 
298 Furthermore, the allene oxide synthase mutant of Arabidopsis thaliana (dde2), deficient in JA 299 biosynthesis, is much more tolerant to high light-induced cell death (at controlled temperature) 300 than the wild-type (Ramel et al., 2013b). Similarly, the acclimation of the Arabidopsis ch1 mutant to 301 excessive light and ${ }^{1} \mathrm{O}_{2}$ stress requires the down-regulation of the JA pathway and JA accumulation 302 (Ramel et al., 2013a).

303 The role of JA in response to excess light appears to be dependent on temperature. When high light 304 is combined with high temperature the dde2 JA mutant is less tolerant than the wild type (Balfagón 305 et al., 2019). In line with these results, JA is known to act together with SA to confer basal 306 thermotolerance (Clarke et al., 2009). This emphasizes further the fact that different light stress 307 conditions induce different, sometimes opposite, physiological responses.

Similarly to JA, both SA and ABA also accumulate in plants exposed to excess light energy (GalvezValdivieso et al., 2009; Lv et al., 2015; Beaugelin et al., 2019). ABA deficiency in Arabidopsis was reported to enhance plant sensitivity to high light (Huang et al., 2019), suggesting a positive role for ABA in stress tolerance. Conversely, the SA-deficient sid2 mutant of Arabidopsis shows enhanced tolerance to high light stress as shown by a marked reduction of lipid peroxidation compared with the wild type (Beaugelin et al., 2019). These results support the finding that SA overaccumulation leads to a ${ }^{1} \mathrm{O}_{2}$ burst in the chloroplast (Lv et al., 2019), resulting in a possible self-amplifying loop. Furthermore, SA biosynthesis is downstream of JA accumulation (Beaugelin et al., 2019), suggesting that the cell death mechanism under abiotic stress is different from the well-known SA-JA antagonism in biotic stress. Clearly, the role of these two stress hormones in plant 320 Emerging evidence has also implicated cytokinin signaling in abiotic stresses related to photosynthetic dysfunction and ROS production (Zwack and Rashotte, 2015; Cortleven et al., 2019). Loss of the cytokinin receptors AHK2 and AHK3 results in greater photooxidative stress tolerance (induced by a combination of water deficit and moderately elevated PFD) as indicated by decreased lipid peroxidation and by chlorophyll loss, and this was interpreted as an indication that cytokinins negatively regulate photooxidative stress tolerance (Danilova et al., 2014). However, in another study (Cortleven et al., 2014), ahk2,3 and arr1,12 double mutants were hypersensitive to high light stress, indicating that cytokinin signaling may play a positive role in this response. Those 
contradictory results illustrate even better the need for standardized conditions in imposing high light stress (i.e. temperature) .

\section{The endoplasmic reticulum in the response to excess light energy}

Although excessive light is a stress that primarily affects the chloroplast, it induces an extended response that can lead to cell death and senescence of a full organ. Counterintuitively, it was recently shown in Nicotiana tabacum seedlings that chloroplastic gene expression and translation showed only limited changes after an increase in PFD from $350 \mu \mathrm{mol}$ photons $\mathrm{m}^{-2} \mathrm{~s}^{-1}$ to $1000 \mu \mathrm{mol}$ $\mathrm{m}^{-2} \mathrm{~s}^{-1}$ at $24^{\circ} \mathrm{C}$ (Schuster et al., 2020). These results are in agreement with the genetic response to excessive light of the Arabidopsis ${ }^{1} \mathrm{O}_{2}$-overproducer mutant $c h 1$, which showed that only $9 \%$ of the total genetic response involved chloroplastic protein-encoding genes (Beaugelin et al., 2020). The vast majority of the response was nuclear, followed by genes encoding mitochondrial proteins and endoplasmic reticulum (ER)-located proteins. A possible explanation for the ER response lies in the extensive modification of proteins caused by RCS.

ER stress is a well-described phenomenon occurring in eukaryotic cells when unfolded or misfolded proteins accumulate in the ER lumen and overwhelm the folding capacity of the ER. Plant signaling in the ER was previously reviewed by Park and Park (2019): ER stress triggers a response called the Unfold Protein Response (UPR) by activating two signaling branches via bZIP28 and IRE1/bZIP60, which can sense and transduce the information (Park and Park, 2019). Both branches are activated when BIP chaperones (binding immunoglobulin proteins) are released from bZIP28 and IRE1 inside the ER and bind to unfolded proteins (Howell, 2013; Nawkar et al., 2018).

Both in plant and animal systems, the ER integrates cellular signals and resides at the intersection between tolerance and cell death responses (Su et al., 2013; Li et al., 2015; Kørner et al., 2015). Evidence that ROS production in chloroplasts and mitochondria triggers the UPR in plants are accumulating, and Ozgur et al. (2015) depicted transcriptional modifications of UPR gene expression upon application of $\mathrm{H}_{2} \mathrm{O}_{2}$, rotenone, methyl viologen or 3-(3,4-dichlorophenyl)-1,1-dimethylurea (DCMU), mimicking organellar ROS production (Ozgur et al., 2015). In agreement with these results, the UPR is triggered in the ${ }^{1} \mathrm{O}_{2}$-overproducing ch1 mutant both under physiological growth conditions (chronic induction) and during excessive light stress (Beaugelin et al., 2020). However, ${ }^{1} \mathrm{O}_{2}$ lifetime has been estimated in the sub- $\mu$ s range in the thylakoid membranes allowing an 
estimated diffusion distance of around only $5.5 \mathrm{~nm}$ (Khorobrykh et al., 2020). Therefore, ${ }^{1} \mathrm{O}_{2}$ must react with molecules in its proximity that then constitute the actual signal mediators (e.g. $\beta$ carotene oxidation products, lipid peroxides, RCS). Walley and co-workers demonstrated that MEcPP, an intermediate of isoprenoid biosynthesis in the chloroplast, was able to activate UPR genes in vivo (Walley et al., 2015). In fact, the accumulation of MEcPP in the Arabidopsis ceh1 mutant causes the constitutive accumulation of SA, which triggers the UPR response in the ER and regulates JA-responsive genes (Xiao et al., 2012; Lemos et al., 2016; Bjornson et al., 2017) .

Under high light conditions, mutants of the UPR signaling pathway have helped to reveal the key role of the ER in triggering cell death mechanisms (Beaugelin et al., 2020). The double mutant bzip60 bzip28 showed an increased sensitivity towards excessive light stress, while pretreatment with tauroursodeoxycholic acid (TUDCA, a chemical chaperone alleviating UPR) leads to increased tolerance (Beaugelin et al., 2020). Moreover, pre-treatment of plants with the ER stress inducer, tunicamycin, was shown to enhance photosensitivity, with the induction of PCD marker genes and the development of leaf cell death and lipid peroxidation under excessive light (Beaugelin et al., 2020). The strict interconnection between chloroplasts and ER stress under excessive light is further demonstrated by AtDAD1 and AtDAD2, two ER-located proteins, which play a key role as inhibitors of excessive light-induced PCD (Beaugelin et al., 2019). DAD proteins appear to act as molecular brakes on the ${ }^{1} \mathrm{O}_{2}$-induced, OXI1/JA/SA-mediated cell death by inhibiting OXI1.

To date ER-mediated PCD is known to involve several mechanisms such as the regulation of pro- or anti-death members of the Bcl-2 family, the induction of plant specific N-rich proteins (NRPs) cell death signaling and the induction of proteins exhibiting caspase-1-like or caspase-3-like activities (Williams et al., 2010; Reis and Fontes, 2012). AtBAG7 is a member of Bcl-2-associated athanogene (BAG) located in the ER. AtBAG7 directly binds to AtBIP2 during UPR and facilitates heat and cold stress tolerance. Carvalho et al. (2014) showed that overexpression of BIP in soybean induces delayed senescence under developmental and abiotic stress conditions, and leads to the attenuation of NRP-mediated cell death (Carvalho et al., 2014). Accordingly, a knockout mutant of BiP3 exhibited an increased sensitivity to high light stress in Arabidopsis (Beaugelin et al., 2020). In NRP-overexpressing soybean lines, the transcription factor GmNAC81 (homologue of ANAC089 in Arabidopsis thaliana) is strongly induced and promote activation of caspase 1- and caspase 3-like activity (Reis and Fontes, 2012). GmNAC81 interacts with GmNAC30 which together bind to the 
promoter of a vacuolar processing enzyme (VPE) involved in PCD (Mendes et al., 2013). Also in Arabidopsis, ANAC089 controls a number of PCD regulators, including MC5, BAG6 and NAC094, under stress conditions (Yang et al., 2014). In agreement, the ${ }^{1} \mathrm{O}_{2}$-overproducing ch1 mutant exhibits an increased expression of ANACO89 under excessive light stress (Beaugelin et al., 2020). Finally, caspase-like activity seems to be a pan-maker of plant PCD mediating excessive light-induced PCD, downstream of RCS and prolonged ER stress signaling .

\section{Why do plants kill leaf cells under excessive light?}

The biological role of PCD is easy to understand in a phytopathological context- it limits further pathogen spreading and triggers defense mechanisms in non-infected neighbor tissues (Morel and Dangl, 1997; Heath, 2000). The physiological relevance of excessive light-induced cell death is less clear. A relevant aspect in this context is the fact that the photoprotective capacity strongly depends on leaf age (Bielczynski et al., 2017; D'Alessandro et al., 2018). In fact, when plants are exposed to excess light, lipid peroxidation is usually much more pronounced in the mature leaves ( $D^{\prime}$ Alessandro et al., 2018) (see Fig. 4). Non-functional photosynthetic tissues become an unnecessary carbon sink, and damaged tissues are more exposed to pathogen attacks (Savatin et al., 2014). Therefore, plants appear to choose to sacrifice old/mature leaves when they are photodamaged and recover important nutrients rather than invest in repair. Also, cell membranes damaged under photooxidative conditions could lead to water loss (Carvalho et al., 2017; Li et al., 2017). Stomatal and leaf hydraulic systems are known to be very responsive to stress conditions, and they can decline even before cell integrity is lost (Trueba et al., 2019). Therefore, PCD may be a means to avoid dramatic water losses from photodamaged leaves, to preserve water relations and promote plant survival. Therefore, preservation of healthy organs by light induced PCD of photooxidized organs is a defense mechanism that can come into play under many environmental constraints.

\section{Main conclusions and some perspectives}

In this review, we provide a broad summary of the literature linking pure excessive light exposure to programmed cell death. We highlight the importance of controlling the conditions of excessive light treatments, particularly leaf temperature, to limit variability between laboratories. In fact, by selecting results based on pure excessive light exposure, and not from the superposition of heat and high light stress, we are able to propose a model explaining how this stress can trigger PCD (Fig. 5). After an initial phase of stress response, in which the role of ${ }^{1} \mathrm{O}_{2}$ is predominant and phototolerance 
mechanism are activated, damage to PSII and the decay of lipid peroxides to RCS leads to the accumulation of reduced forms of oxygen. $\mathrm{H}_{2} \mathrm{O}_{2}$ further enhances the increase in RCS by limiting cellular detoxification, leading to ER stress. If the stress does not cease, ER stress may then lead to the activation of PCD induced by caspase-like activity. At the same time, overproduction of ${ }^{1} \mathrm{O}_{2}$ may activate EX1 at the grana margins, together with the OXI1/JA/SA controlled PCD.

Although we were able to identify several steps in the response to excessive light, many questions remain to be elucidated. First of all, we know that our knowledge of phototolerance mechanisms is not exhaustive, and that many molecular players in apocarotenoid sensing remain elusive. It is not clear if the signaling of those metabolites interacts with other known retrograde signaling pathways. Finally, PCD may be mediated by at least three pathways in our model, and the connections and interrelations between caspase-like inducers of PCD and EX1- and OXI1-induced PCD remain unknown. Therefore, it is pivotal in our opinion to find similar working conditions between laboratories to maximize the compatibility between the results. At the same time, the substantial difference between excessive light alone or in combination with heat shock highlights the importance of studying stress combinations.

\section{Author contributions}

S.D. and M.H. planned, structured, and wrote the article; I.B. contributed to the article.

\section{Acknowledgments}

We would like to thank Dr. Benjamin Field (CNRS) for improving the use of English in the text. We would like to acknowledge funding from the French National Research Agency (ANR project SLOSAM, 14-CE02-0010-02). No conflict of interest declared.

\section{REFERENCES}

Alric, J., and Johnson, X. (2017). Alternative electron transport pathways in photosynthesis: a confluence of regulation. Curr. Opin. Plant Biol. 37:78-86.

Alsharafa, K., Vogel, M. O., Oelze, M.-L., Moore, M., Stingl, N., König, K., Friedman, H., Mueller, M. J., and Dietz, K.-J. (2014). Kinetics of retrograde signalling initiation in the high light response of Arabidopsis thaliana. Philos. Trans. R. Soc. Lond., B, Biol. Sci. 369:20130424.

Ameye, M., Allmann, S., Verwaeren, J., Smagghe, G., Haesaert, G., Schuurink, R. C., and Audenaert, K. (2018). Green leaf volatile production by plants: a meta-analysis. New Phytol. 220:666-683. 
Apel, K., and Hirt, H. (2004). REACTIVE OXYGEN SPECIES: Metabolism, Oxidative Stress, and Signal Transduction. Annu. Rev. Plant Biol. 55:373-399.

Balfagón, D., Sengupta, S., Gómez-Cadenas, A., Fritschi, F. B., Azad, R. K., Mittler, R., and Zandalinas, S. I. (2019). Jasmonic Acid Is Required for Plant Acclimation to a Combination of High Light and Heat Stress. Plant Physiology 181:1668-1682.

Bauer, G., and Zarkovic, N. (2015). Revealing mechanisms of selective, concentration-dependent potentials of 4-hydroxy-2-nonenal to induce apoptosis in cancer cells through inactivation of membraneassociated catalase. Free Radic. Biol. Med. 81:128-144.

Beaugelin, I., Chevalier, A., D’Alessandro, S., Ksas, B., Novák, O., Strnad, M., Forzani, C., Hirt, H., Havaux, M., and Monnet, F. (2019). OXI1 and DAD Regulate Light-Induced Cell Death Antagonistically through Jasmonate and Salicylate Levels. Plant Physiology 180:1691-1708.

Beaugelin, I., Chevalier, A., D'Alessandro, S., Ksas, B., and Havaux, M. (2020). Endoplasmic reticulummediated unfolded protein response is an integral part of singlet oxygen signalling in plants. Plant J. Advance Access published January 23, 2020, doi:10.1111/tpj.14700.

Berry, J., and Bjorkman, O. (1980). Photosynthetic Response and Adaptation to Temperature in Higher Plants. Annual Review of Plant Physiology 31:491-543.

Bielczynski, L. W., Łącki, M. K., Hoefnagels, I., Gambin, A., and Croce, R. (2017). Leaf and Plant Age Affects Photosynthetic Performance and Photoprotective Capacity. Plant Physiology 175:1634-1648.

Birtic, S., Ksas, B., Genty, B., Mueller, M. J., Triantaphylidès, C., and Havaux, M. (2011). Using spontaneous photon emission to image lipid oxidation patterns in plant tissues. The Plant Journal 67:1103-1115.

Biswas, M. S., and Mano, J. (2016). Reactive Carbonyl Species Activate Caspase-3-Like Protease to Initiate Programmed Cell Death in Plants. Plant Cell Physiol 57:1432-1442.

Biswas, M. S., Terada, R., and Mano, J. (2020). Inactivation of Carbonyl-Detoxifying Enzymes by H2O2 Is a Trigger to Increase Carbonyl Load for Initiating Programmed Cell Death in Plants. Antioxidants (Basel) 9.

Bjornson, M., Balcke, G. U., Xiao, Y., de Souza, A., Wang, J.-Z., Zhabinskaya, D., Tagkopoulos, I., Tissier, A., and Dehesh, K. (2017). Integrated omics analyses of retrograde signaling mutant delineate interrelated stress-response strata. Plant J. 91:70-84.

Bour, A., Kruglik, S. G., Chabanon, M., Rangamani, P., Puff, N., and Bonneau, S. (2019). Lipid Unsaturation Properties Govern the Sensitivity of Membranes to Photoinduced Oxidative Stress. Biophysical Journal 116:910-920.

Carvalho, H. H., Silva, P. A., Mendes, G. C., Brustolini, O. J. B., Pimenta, M. R., Gouveia, B. C., Valente, M. A. S., Ramos, H. J. O., Soares-Ramos, J. R. L., and Fontes, E. P. B. (2014). The Endoplasmic Reticulum Binding Protein BiP Displays Dual Function in Modulating Cell Death Events. Plant Physiology 164:654-670.

Carvalho, R. C. de, Catalá, M., Branquinho, C., Silva, J. M. da, and Barreno, E. (2017). Dehydration rate determines the degree of membrane damage and desiccation tolerance in bryophytes. Physiologia Plantarum 159:277-289.

Chapman, D. J., and Barber, J. (1986). Analysis of plastoquinone-9 levels in appressed and non-appressed thylakoid membrane regions. Biochimica et Biophysica Acta (BBA) - Bioenergetics 850:170-172. 
Clarke, S. M., Cristescu, S. M., Miersch, O., Harren, F. J. M., Wasternack, C., and Mur, L. A. J. (2009). Jasmonates act with salicylic acid to confer basal thermotolerance in Arabidopsis thaliana. New Phytol. 182:175-187.

Collado-González, J., Pérez-López, D., Memmi, H., Gijón, M. C., Medina, S., Durand, T., Guy, A., Galano, J.M., Fernández, D. J., Carro, F., et al. (2016). Effect of the season on the free phytoprostane content in Cornicabra extra virgin olive oil from deficit-irrigated olive trees. J. Sci. Food Agric. 96:1585-1592.

Colzani, M., Aldini, G., and Carini, M. (2013). Mass spectrometric approaches for the identification and quantification of reactive carbonyl species protein adducts. J Proteomics 92:28-50.

Cortleven, A., Nitschke, S., Klaumünzer, M., Abdelgawad, H., Asard, H., Grimm, B., Riefler, M., and Schmülling, T. (2014). A novel protective function for cytokinin in the light stress response is mediated by the Arabidopsis histidine kinase 2 and Arabidopsis histidine kinase3 receptors. Plant Physiol. 164:1470-1483.

Cortleven, A., Leuendorf, J. E., Frank, M., Pezzetta, D., Bolt, S., and Schmülling, T. (2019). Cytokinin action in response to abiotic and biotic stresses in plants. Plant Cell Environ. 42:998-1018.

D'Alessandro, S., and Havaux, M. (2019). Sensing $\beta$-carotene oxidation in photosystem II to master plant stress tolerance. New Phytologist 223:1776-1783.

D'Alessandro, S., Ksas, B., and Havaux, M. (2018). Decoding $\beta$-Cyclocitral-Mediated Retrograde Signaling Reveals the Role of a Detoxification Response in Plant Tolerance to Photooxidative Stress. The Plant Cell 30:2495-2511.

Danilova, M. N., Kudryakova, N. V., Voronin, P. Yu., Oelmüller, R., Kusnetsov, V. V., and Kulaeva, O. N. (2014). Membrane receptors of cytokinin and their regulatory role in Arabidopsis thaliana plant response to photooxidative stress under conditions of water deficit. Russ J Plant Physiol 61:434442.

Dogra, V., and Kim, C. (2020). Singlet Oxygen Metabolism: From Genesis to Signaling. Front Plant Sci 10:1640.

Dogra, V., Rochaix, J.-D., and Kim, C. (2018). Singlet oxygen-triggered chloroplast-to-nucleus retrograde signalling pathways: An emerging perspective. Plant Cell Environ. 41:1727-1738.

Dogra, V., Li, M., Singh, S., Li, M., and Kim, C. (2019). Oxidative post-translational modification of EXECUTER1 is required for singlet oxygen sensing in plastids. Nat Commun 10:2834.

Douce, R., and Joyard, J. (1980). 12 - Plant Galactolipids. In Lipids: Structure and Function (ed. Stumpf, P. K.), pp. 321-362. Academic Press.

Durand, T., Bultel-Poncé, V., Guy, A., El Fangour, S., Rossi, J.-C., and Galano, J.-M. (2011). Isoprostanes and phytoprostanes: Bioactive lipids. Biochimie 93:52-60.

Exposito-Rodriguez, M., Laissue, P. P., Yvon-Durocher, G., Smirnoff, N., and Mullineaux, P. M. (2017). Photosynthesis-dependent $\mathrm{H} 2 \mathrm{O} 2$ transfer from chloroplasts to nuclei provides a high-light signalling mechanism. Nature Communications 8:49.

Farmer, E. E., and Mueller, M. J. (2013). ROS-mediated lipid peroxidation and RES-activated signaling. Annu Rev Plant Biol 64:429-450. 
Filiz, E., Ozyigit, I. I., Saracoglu, I. A., Uras, M. E., Sen, U., and Yalcin, B. (2019). Abiotic stress-induced regulation of antioxidant genes in different Arabidopsis ecotypes: microarray data evaluation. Biotechnology \& Biotechnological Equipment 33:128-143.

Fode, B., Siemsen, T., Thurow, C., Weigel, R., and Gatz, C. (2008). The Arabidopsis GRAS Protein SCL14 Interacts with Class II TGA Transcription Factors and Is Essential for the Activation of StressInducible Promoters. The Plant Cell 20:3122-3135.

Galano, J.-M., Lee, Y. Y., Oger, C., Vigor, C., Vercauteren, J., Durand, T., Giera, M., and Lee, J. C.-Y. (2017). Isoprostanes, neuroprostanes and phytoprostanes: An overview of 25years of research in chemistry and biology. Prog. Lipid Res. 68:83-108.

Galvez-Valdivieso, G., Fryer, M. J., Lawson, T., Slattery, K., Truman, W., Smirnoff, N., Asami, T., Davies, W. J., Jones, A. M., Baker, N. R., et al. (2009). The High Light Response in Arabidopsis Involves ABA Signaling between Vascular and Bundle Sheath Cells. The Plant Cell 21:2143-2162.

Garai, S., and Tripathy, B. C. (2018). Alleviation of Nitrogen and Sulfur Deficiency and Enhancement of Photosynthesis in Arabidopsis thaliana by Overexpression of Uroporphyrinogen III Methyltransferase (UPM1). Front. Plant Sci. 8.

Havaux, M. (1993). Rapid photosynthetic adaptation to heat stress triggered in potato leaves by moderately elevated temperatures. Plant, Cell \& Environment 16:461-467.

Heath, M. C. (2000). Hypersensitive response-related death. Plant Mol Biol 44:321-334.

Howden, A. J. M., Salek, M., Miguet, L., Pullen, M., Thomas, B., Knight, M. R., and Sweetlove, L. J. (2011). The phosphoproteome of Arabidopsis plants lacking the oxidative signal-inducible1 (OXI1) protein kinase. New Phytol. 190:49-56.

Howell, S. H. (2013). Endoplasmic reticulum stress responses in plants. Annu Rev Plant Biol 64:477-499.

Huang, J., Zhao, X., and Chory, J. (2019). The Arabidopsis Transcriptome Responds Specifically and Dynamically to High Light Stress. Cell Rep 29:4186-4199.e3.

Järvi, S., Suorsa, M., and Aro, E.-M. (2015). Photosystem II repair in plant chloroplasts--Regulation, assisting proteins and shared components with photosystem II biogenesis. Biochim. Biophys. Acta 1847:900-909.

Kato, M. C., Hikosaka, K., Hirotsu, N., Makino, A., and Hirose, T. (2003). The Excess Light Energy that is neither Utilized in Photosynthesis nor Dissipated by Photoprotective Mechanisms Determines the Rate of Photoinactivation in Photosystem II. Plant Cell Physiol 44:318-325.

Kato, Y., Hyodo, K., and Sakamoto, W. (2018). The Photosystem II Repair Cycle Requires FtsH Turnover through the EngA GTPase. Plant Physiology 178:596-611.

Khorobrykh, S., Havurinne, V., Mattila, H., and Tyystjärvi, E. (2020). Oxygen and ROS in Photosynthesis. Plants 9:91.

Kono, M., Noguchi, K., and Terashima, I. (2014). Roles of the Cyclic Electron Flow Around PSI (CEF-PSI) and O2-Dependent Alternative Pathways in Regulation of the Photosynthetic Electron Flow in ShortTerm Fluctuating Light in Arabidopsis thaliana. Plant Cell Physiol 55:990-1004. 
Kørner, C. J., Du, X., Vollmer, M. E., and Pajerowska-Mukhtar, K. M. (2015). Endoplasmic Reticulum Stress Signaling in Plant Immunity-At the Crossroad of Life and Death. International Journal of Molecular Sciences 16:26582-26598.

Kreuz, K., Tommasini, R., and Martinoia, E. (1996). Old Enzymes for a New Job (Herbicide Detoxification in Plants). Plant Physiology 111:349-353.

Krieger-Liszkay, A., Fufezan, C., and Trebst, A. (2008). Singlet oxygen production in photosystem II and related protection mechanism. Photosynth Res 98:551-564.

Laloi, C., and Havaux, M. (2015). Key players of singlet oxygen-induced cell death in plants. Front Plant Sci 6.

Lemos, M., Xiao, Y., Bjornson, M., Wang, J.-Z., Hicks, D., Souza, A. de, Wang, C.-Q., Yang, P., Ma, S., Dinesh-Kumar, S., et al. (2016). The plastidial retrograde signal methyl erythritol cyclopyrophosphate is a regulator of salicylic acid and jasmonic acid crosstalk. J. Exp. Bot. 67:15571566.

Li, Z., Wakao, S., Fischer, B. B., and Niyogi, K. K. (2009). Sensing and Responding to Excess Light. Annu. Rev. Plant Biol. 60:239-260.

Li, X., Wang, Y., Wang, H., Huang, C., Huang, Y., and Li, J. (2015). Endoplasmic reticulum stress is the crossroads of autophagy, inflammation, and apoptosis signaling pathways and participates in liver fibrosis. Inflamm. Res. 64:1-7.

Li, W., Nguyen, K. H., Chu, H. D., Ha, C. V., Watanabe, Y., Osakabe, Y., Leyva-González, M. A., Sato, M., Toyooka, K., Voges, L., et al. (2017). The karrikin receptor KAI2 promotes drought resistance in Arabidopsis thaliana. PLOS Genetics 13:e1007076.

Li-Beisson, Y., Shorrosh, B., Beisson, F., Andersson, M. X., Arondel, V., Bates, P. D., Baud, S., Bird, D., Debono, A., Durrett, T. P., et al. (2013). Acyl-lipid metabolism. Arabidopsis Book 11:e0161.

Liebler, D. C. (2008). Protein damage by reactive electrophiles: targets and consequences. Chem. Res. Toxicol. 21:117-128.

Liu, L., Sonbol, F.-M., Huot, B., Gu, Y., Withers, J., Mwimba, M., Yao, J., He, S. Y., and Dong, X. (2016). Salicylic acid receptors activate jasmonic acid signalling through a non-canonical pathway to promote effector-triggered immunity. Nature Communications 7:1-10.

Loeffler, C., Berger, S., Guy, A., Durand, T., Bringmann, G., Dreyer, M., Rad, U. von, Durner, J., and Mueller, M. J. (2005). B1-Phytoprostanes Trigger Plant Defense and Detoxification Responses. Plant Physiology 137:328-340.

Lupette, J., Jaussaud, A., Vigor, C., Oger, C., Galano, J.-M., Réversat, G., Vercauteren, J., Jouhet, J., Durand, T., and Maréchal, E. (2018). Non-Enzymatic Synthesis of Bioactive Isoprostanoids in the Diatom Phaeodactylum following Oxidative Stress. Plant Physiology 178:1344-1357.

Lv, F., Zhou, J., Zeng, L., and Xing, D. (2015). $\beta$-cyclocitral upregulates salicylic acid signalling to enhance excess light acclimation in Arabidopsis. J Exp Bot 66:4719-4732.

Lv, R., Li, Z., Li, M., Dogra, V., Lv, S., Liu, R., Lee, K. P., and Kim, C. (2019). Uncoupled Expression of Nuclear and Plastid Photosynthesis-Associated Genes Contributes to Cell Death in a Lesion Mimic Mutant. Plant Cell 31:210-230. 
Mano, J. (2012). Reactive carbonyl species: Their production from lipid peroxides, action in environmental stress, and the detoxification mechanism. Plant Physiology and Biochemistry 59:90-97.

Mano, J., Torii, Y., Hayashi, S., Takimoto, K., Matsui, K., Nakamura, K., Inzé, D., Babiychuk, E., Kushnir, S., and Asada, K. (2002). The NADPH:Quinone Oxidoreductase P1-ל-crystallin in Arabidopsis Catalyzes the $\alpha, \beta$-Hydrogenation of 2-Alkenals: Detoxication of the Lipid Peroxide-Derived Reactive Aldehydes. Plant Cell Physiol 43:1445-1455.

Mano, J., Nagata, M., Okamura, S., Shiraya, T., and Mitsui, T. (2014). Identification of oxidatively modified proteins in salt-stressed Arabidopsis: a carbonyl-targeted proteomics approach. Plant Cell Physiol. 55:1233-1244.

Mano, J., Ishibashi, A., Muneuchi, H., Morita, C., Sakai, H., Biswas, M. S., Koeduka, T., and Kitajima, S. (2017). Acrolein-detoxifying isozymes of glutathione transferase in plants. Planta 245:255-264.

Mano, J., Kanameda, S., Kuramitsu, R., Matsuura, N., and Yamauchi, Y. (2019a). Detoxification of Reactive Carbonyl Species by Glutathione Transferase Tau Isozymes. Front Plant Sci 10.

Mano, J., Biswas, M. S., and Sugimoto, K. (2019b). Reactive Carbonyl Species: A Missing Link in ROS Signaling. Plants (Basel) 8.

Mattila, H., Mishra, K. B., Kuusisto, I., Mishra, A., Novotná, K., Šebela, D., and Tyystjärvi, E. (2019). Effects of low temperature and cold-acclimation on photoinhibition and singlet oxygen production in four natural accessions of Arabidopsis. bioRxiv Advance Access published September 20, 2019, doi:10.1101/777060.

Mendes, G. C., Reis, P. A. B., Calil, I. P., Carvalho, H. H., Aragão, F. J. L., and Fontes, E. P. B. (2013). GmNAC30 and GmNAC81 integrate the endoplasmic reticulum stress- and osmotic stress-induced cell death responses through a vacuolar processing enzyme. Proc Natl Acad Sci U S A 110:1962719632.

Mène-Saffrané, L., Dubugnon, L., Chételat, A., Stolz, S., Gouhier-Darimont, C., and Farmer, E. E. (2009). Nonenzymatic oxidation of trienoic fatty acids contributes to reactive oxygen species management in Arabidopsis. J. Biol. Chem. 284:1702-1708.

Montané, M.-H., Tardy, F., Kloppstech, K., and Havaux, M. (1998). Differential control of xanthophylls and light-induced stress proteins, as opposed to light-harvesting chlorophyll a/b proteins, during photosynthetic acclimation of barley leaves to light irradiance. Plant Physiol. 118:227-235.

Morel, J. B., and Dangl, J. L. (1997). The hypersensitive response and the induction of cell death in plants. Cell Death Differ. 4:671-683.

Mueller, M. J. (2004). Archetype signals in plants: the phytoprostanes. Curr. Opin. Plant Biol. 7:441-448.

Mueller, S., Hilbert, B., Dueckershoff, K., Roitsch, T., Krischke, M., Mueller, M. J., and Berger, S. (2008). General Detoxification and Stress Responses Are Mediated by Oxidized Lipids through TGA Transcription Factors in Arabidopsis. The Plant Cell 20:768-785.

Murata, N., Takahashi, S., Nishiyama, Y., and Allakhverdiev, S. I. (2007). Photoinhibition of photosystem II under environmental stress. Biochim. Biophys. Acta 1767:414-421.

Nath, K., Jajoo, A., Poudyal, R. S., Timilsina, R., Park, Y. S., Aro, E.-M., Nam, H. G., and Lee, C.-H. (2013). Towards a critical understanding of the photosystem II repair mechanism and its regulation during stress conditions. FEBS Letters 587:3372-3381. 
Nawkar, G. M., Lee, E. S., Shelake, R. M., Park, J. H., Ryu, S. W., Kang, C. H., and Lee, S. Y. (2018). Activation of the Transducers of Unfolded Protein Response in Plants. Front Plant Sci 9.

Noctor, G., Reichheld, J.-P., and Foyer, C. H. (2018). ROS-related redox regulation and signaling in plants. Semin. Cell Dev. Biol. 80:3-12.

Ort, D. R. (2001). When There Is Too Much Light. Plant Physiology 125:29-32.

Ozgur, R., Uzilday, B., Sekmen, A. H., and Turkan, I. (2015). The effects of induced production of reactive oxygen species in organelles on endoplasmic reticulum stress and on the unfolded protein response in arabidopsis. Ann. Bot. 116:541-553.

Park, C.-J., and Park, J. M. (2019). Endoplasmic Reticulum Plays a Critical Role in Integrating Signals Generated by Both Biotic and Abiotic Stress in Plants. Front. Plant Sci. 10.

Pérez-Bueno, M. L., Pineda, M., and Barón, M. (2019). Phenotyping Plant Responses to Biotic Stress by Chlorophyll Fluorescence Imaging. Front. Plant Sci. 10.

Ramel, F., Birtic, S., Ginies, C., Soubigou-Taconnat, L., Triantaphylidès, C., and Havaux, M. (2012). Carotenoid oxidation products are stress signals that mediate gene responses to singlet oxygen in plants. PNAS 109:5535-5540.

Ramel, F., Ksas, B., Akkari, E., Mialoundama, A. S., Monnet, F., Krieger-Liszkay, A., Ravanat, J.-L., Mueller, M. J., Bouvier, F., and Havaux, M. (2013a). Light-Induced Acclimation of the Arabidopsis chlorina1 Mutant to Singlet Oxygen. The Plant Cell 25:1445-1462.

Ramel, F., Ksas, B., and Havaux, M. (2013b). Jasmonate: A decision maker between cell death and acclimation in the response of plants to singlet oxygen. Plant Signaling \& Behavior 8:e26655.

Reinbothe, C., Springer, A., Samol, I., and Reinbothe, S. (2009). Plant oxylipins: role of jasmonic acid during programmed cell death, defence and leaf senescence. FEBS J. 276:4666-4681.

Reis, P. A. B., and Fontes, E. P. B. (2012). N-rich protein (NRP)-mediated cell death signaling: a new branch of the ER stress response with implications for plant biotechnology. Plant Signal Behav 7:628-632.

Rentel, M. C., Lecourieux, D., Ouaked, F., Usher, S. L., Petersen, L., Okamoto, H., Knight, H., Peck, S. C., Grierson, C. S., Hirt, H., et al. (2004). OXI1 kinase is necessary for oxidative burst-mediated signalling in Arabidopsis. Nature 427:858-861.

Riechers, D. E., Kreuz, K., and Zhang, Q. (2010). Detoxification without Intoxication: Herbicide Safeners Activate Plant Defense Gene Expression. Plant Physiol 153:3-13.

Roach, T., and Krieger-Liszkay, A. (2019). Photosynthetic Regulatory Mechanisms for Efficiency and Prevention of Photo-Oxidative Stress. In Annual Plant Reviews online, pp. 273-306. American Cancer Society.

SAITO, R., SHIMAKAWA, G., NISHI, A., IWAMOTO, T., SAKAMOTO, K., YAMAMOTO, H., AMAKO, K., MAKINO, A., and MIYAKE, C. (2013). Functional Analysis of the AKR4C Subfamily of Arabidopsis thaliana: Model Structures, Substrate Specificity, Acrolein Toxicity, and Responses to Light and [CO2]. Bioscience, Biotechnology, and Biochemistry 77:2038-2045.

Sandermann, H. (1992). Plant metabolism of xenobiotics. Trends Biochem. Sci. 17:82-84. 
Savatin, D. V., Gramegna, G., Modesti, V., and Cervone, F. (2014). Wounding in the plant tissue: the defense of a dangerous passage. Front Plant Sci 5.

Savchenko, T., Yanykin, D., Khorobrykh, A., Terentyev, V., Klimov, V., and Dehesh, K. (2017). The hydroperoxide lyase branch of the oxylipin pathway protects against photoinhibition of photosynthesis. Planta 245:1179-1192.

Schuster, M., Gao, Y., Schöttler, M. A., Bock, R., and Zoschke, R. (2020). Limited Responsiveness of Chloroplast Gene Expression during Acclimation to High Light in Tobacco. Plant Physiol. 182:424435.

Shao, N., Duan, G. Y., and Bock, R. (2013). A Mediator of Singlet Oxygen Responses in Chlamydomonas reinhardtii and Arabidopsis Identified by a Luciferase-Based Genetic Screen in Algal Cells. The Plant Cell 25:4209-4226.

Shumbe, L., Chevalier, A., Legeret, B., Taconnat, L., Monnet, F., and Havaux, M. (2016). Singlet OxygenInduced Cell Death in Arabidopsis under High-Light Stress Is Controlled by OXI1 Kinase. Plant Physiology 170:1757-1771.

Shumbe, L., D'Alessandro, S., Shao, N., Chevalier, A., Ksas, B., Bock, R., and Havaux, M. (2017). METHYLENE BLUE SENSITIVITY 1 (MBS1) is required for acclimation of Arabidopsis to singlet oxygen and acts downstream of $\beta$-cyclocitral. Plant, Cell \& Environment 40:216-226.

Smirnoff, N., and Arnaud, D. (2019). Hydrogen peroxide metabolism and functions in plants. New Phytol. 221:1197-1214.

Srivastava, S., Brychkova, G., Yarmolinsky, D., Soltabayeva, A., Samani, T., and Sagi, M. (2017). Aldehyde Oxidase 4 Plays a Critical Role in Delaying Silique Senescence by Catalyzing Aldehyde Detoxification. Plant Physiology 173:1977-1997.

Stiti, N., Missihoun, T. D., Kotchoni, S., Kirch, H.-H., and Bartels, D. (2011). Aldehyde Dehydrogenases in Arabidopsis thaliana: Biochemical Requirements, Metabolic Pathways, and Functional Analysis. Front. Plant Sci. 2.

Su, J., Zhou, L., Kong, X., Yang, X., Xiang, X., Zhang, Y., Li, X., and Sun, L. (2013).Journal of Diabetes Research. https://www.hindawi.com/journals/jdr/2013/193461/ Accessed April 24, 2020.

Tolson, A. H., and Wang, H. (2010). Regulation of drug-metabolizing enzymes by xenobiotic receptors: PXR and CAR. Adv Drug Deliv Rev 62:1238-1249.

Torres, C. A., Sepúlveda, G., and Kahlaoui, B. (2017). Phytohormone Interaction Modulating Fruit Responses to Photooxidative and Heat Stress on Apple (Malus domestica Borkh.). Front Plant Sci 8:2129.

Triantaphylidès, C., Krischke, M., Hoeberichts, F. A., Ksas, B., Gresser, G., Havaux, M., Breusegem, F. V., and Mueller, M. J. (2008). Singlet Oxygen Is the Major Reactive Oxygen Species Involved in Photooxidative Damage to Plants. Plant Physiology 148:960-968.

Trueba, S., Pan, R., Scoffoni, C., John, G. P., Davis, S. D., and Sack, L. (2019). Thresholds for leaf damage due to dehydration: declines of hydraulic function, stomatal conductance and cellular integrity precede those for photochemistry. New Phytol. 223:134-149. 
Wagner, D., Przybyla, D., Camp, R. op den, Kim, C., Landgraf, F., Lee, K. P., Würsch, M., Laloi, C., Nater, M., Hideg, E., et al. (2004). The Genetic Basis of Singlet Oxygen Induced Stress Responses of Arabidopsis thaliana. Science 306:1183-1185.

Walley, J., Xiao, Y., Wang, J.-Z., Baidoo, E. E., Keasling, J. D., Shen, Z., Briggs, S. P., and Dehesh, K. (2015). Plastid-produced interorgannellar stress signal MEcPP potentiates induction of the unfolded protein response in endoplasmic reticulum. Proc. Natl. Acad. Sci. U.S.A. 112:6212-6217.

Wang, L., Kim, C., Xu, X., Piskurewicz, U., Dogra, V., Singh, S., Mahler, H., and Apel, K. (2016). Singlet oxygen- and EXECUTER1-mediated signaling is initiated in grana margins and depends on the protease FtsH2. Proc. Natl. Acad. Sci. U.S.A. 113:E3792-3800.

Wang, Z., Li, G., Sun, H., Ma, L., Guo, Y., Zhao, Z., Gao, H., and Mei, L. (2018). Effects of drought stress on photosynthesis and photosynthetic electron transport chain in young apple tree leaves. Biol Open 7.

Wang, L., Leister, D., Guan, L., Zheng, Y., Schneider, K., Lehmann, M., Apel, K., and Kleine, T. (2020). The Arabidopsis SAFEGUARD1 suppresses singlet oxygen-induced stress responses by protecting grana margins. Proc. Natl. Acad. Sci. U.S.A. 117:6918-6927.

Weis, E., and Berry, J. A. (1988). Plants and high temperature stress. Symp. Soc. Exp. Biol. 42:329-346.

Wierstra, I., and Kloppstech, K. (2000). Differential effects of methyl jasmonate on the expression of the early light-inducible proteins and other light-regulated genes in barley. Plant Physiol. 124:833-844.

Williams, B., Kabbage, M., Britt, R., and Dickman, M. B. (2010). AtBAG7, an Arabidopsis Bcl-2-associated athanogene, resides in the endoplasmic reticulum and is involved in the unfolded protein response. PNAS 107:6088-6093.

Xiao, Y., Savchenko, T., Baidoo, E. E. K., Chehab, W. E., Hayden, D. M., Tolstikov, V., Corwin, J. A., Kliebenstein, D. J., Keasling, J. D., and Dehesh, K. (2012). Retrograde signaling by the plastidial metabolite MEcPP regulates expression of nuclear stress-response genes. Cell 149:1525-1535.

Yalcinkaya, T., Uzilday, B., Ozgur, R., Turkan, I., and Mano, J. (2019). Lipid peroxidation-derived reactive carbonyl species (RCS): Their interaction with ROS and cellular redox during environmental stresses. Environmental and Experimental Botany 165:139-149.

Yamauchi, Y., Hasegawa, A., Taninaka, A., Mizutani, M., and Sugimoto, Y. (2011). NADPH-dependent Reductases Involved in the Detoxification of Reactive Carbonyls in Plants. J. Biol. Chem. 286:69997009.

Yamauchi, Y., Hasegawa, A., Mizutani, M., and Sugimoto, Y. (2012). Chloroplastic NADPH-dependent alkenal/one oxidoreductase contributes to the detoxification of reactive carbonyls produced under oxidative stress. FEBS Letters 586:1208-1213.

Yamori, W., Makino, A., and Shikanai, T. (2016). A physiological role of cyclic electron transport around photosystem I in sustaining photosynthesis under fluctuating light in rice. Scientific Reports 6:20147.

Yang, Z.-T., Wang, M.-J., Sun, L., Lu, S.-J., Bi, D.-L., Sun, L., Song, Z.-T., Zhang, S.-S., Zhou, S.-F., and Liu, J.X. (2014). The Membrane-Associated Transcription Factor NAC089 Controls ER-Stress-Induced Programmed Cell Death in Plants. PLOS Genetics 10:e1004243. 
Yonny, M. E., Rodríguez Torresi, A., Cuyamendous, C., Réversat, G., Oger, C., Galano, J.-M., Durand, T., Vigor, C., and Nazareno, M. A. (2016). Thermal Stress in Melon Plants: Phytoprostanes and Phytofurans as Oxidative Stress Biomarkers and the Effect of Antioxidant Supplementation. J. Agric. Food Chem. 64:8296-8304.

Yoshioka-Nishimura, M. (2016). Close Relationships Between the PSII Repair Cycle and Thylakoid Membrane Dynamics. Plant Cell Physiol 57:1115-1122.

Zandalinas, S. I., Fichman, Y., Devireddy, A. R., Sengupta, S., Azad, R. K., and Mittler, R. (2020). Systemic signaling during abiotic stress combination in plants. PNAS Advance Access published May 29, 2020, doi:10.1073/pnas.2005077117.

Zwack, P. J., and Rashotte, A. M. (2015). Interactions between cytokinin signalling and abiotic stress responses. J. Exp. Bot. 66:4863-4871. 
A

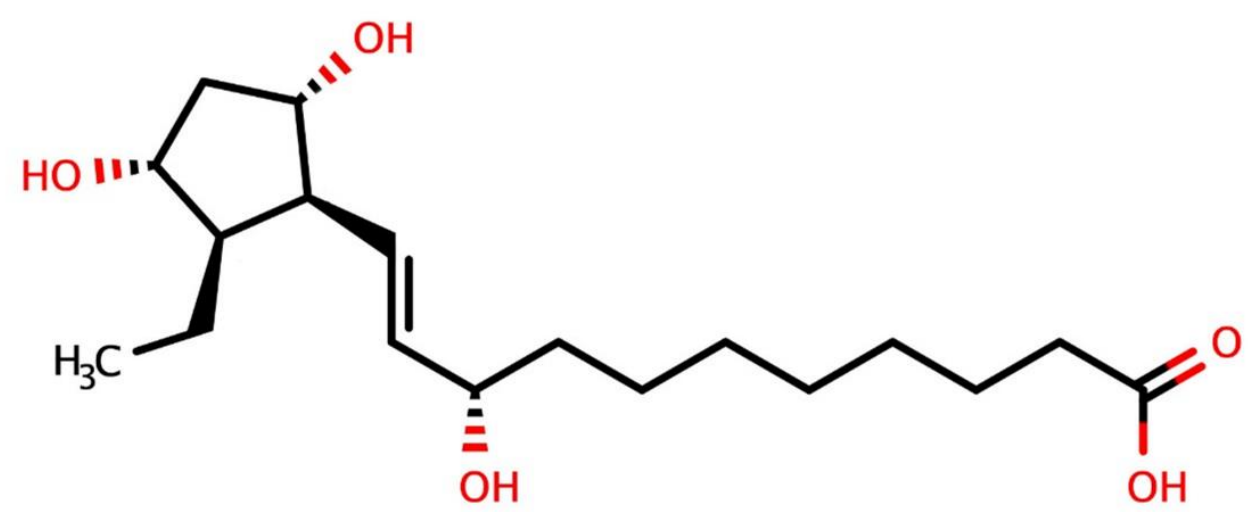

B<smiles>O=CCC=O</smiles>

C<smiles>C=CC=O</smiles>

D

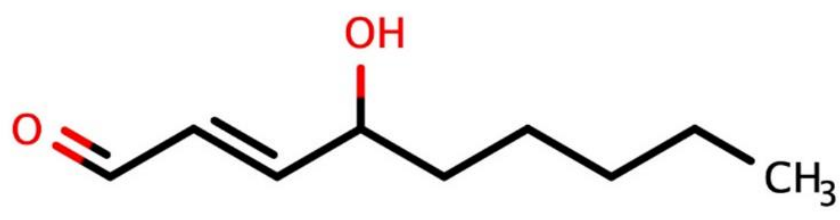

784 Figure 1. Examples of secondary products generated by lipid peroxidation in plant leaves: A) 9-F1-

Phytoprostane, B) malondialdehyde (MDA), C) acrolein, D) 4-hydroxynonenal (HNE).

\section{Phase I modification}

Alkenal Reductases (AER)

Aldo-Keto Reductases (AKR)

Short chain Dehydrogenases/Reductases (SDR)

Aldehyde Dehydrogenases (ALDH)

Cytochrome P450 oxidases (CYP)

Peroxidases
Phase II conjugation

Glycosyl transferases (UGT)

Sulphotransferase (SOT)

Glutathione-S-transferases (GST)
Phase III compartmentalization

ATP-binding cassette $(\mathrm{ABC})$ transporters

787 Figure 2. The xenobiotic detoxification response is composed of three phases involving families of detoxifying enzymes. 


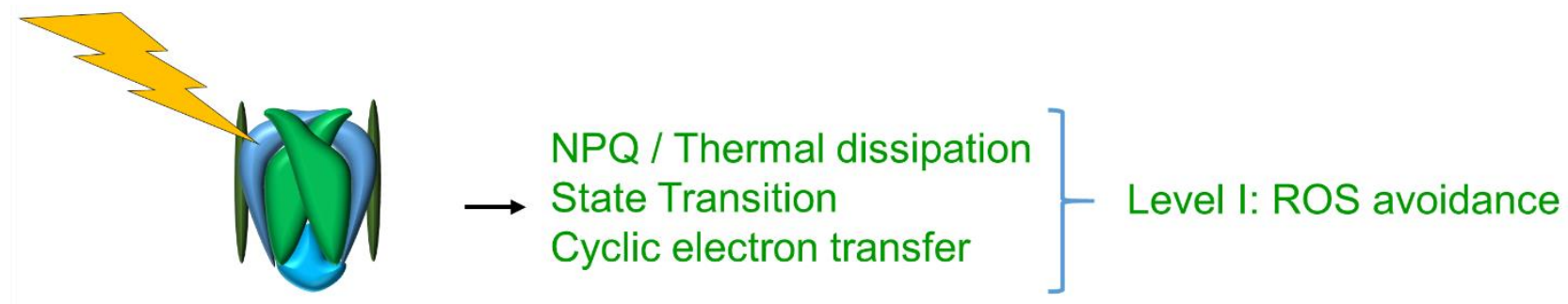

Photosystems
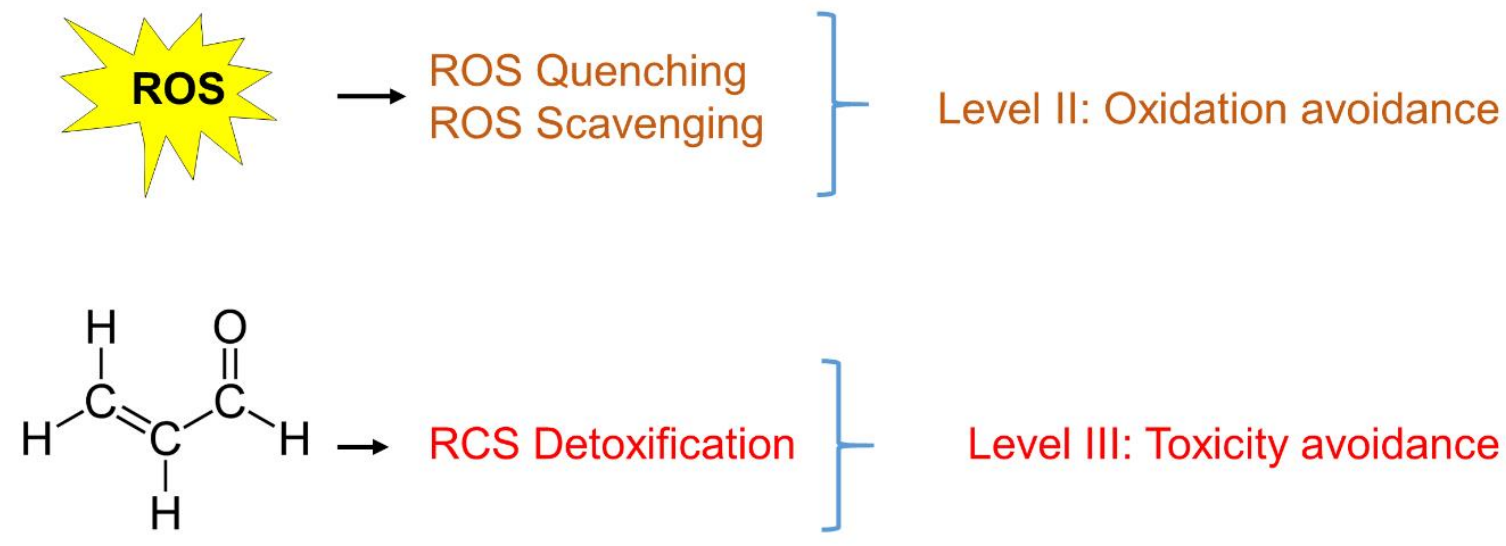

RCS (Acrolein)

Figure 3. Different levels of photoprotective mechanisms are present in plants to sequentially (1) limit ROS photoproduction, (2) ROS-induced oxidation and (3) toxicity of photooxidation byproducts.
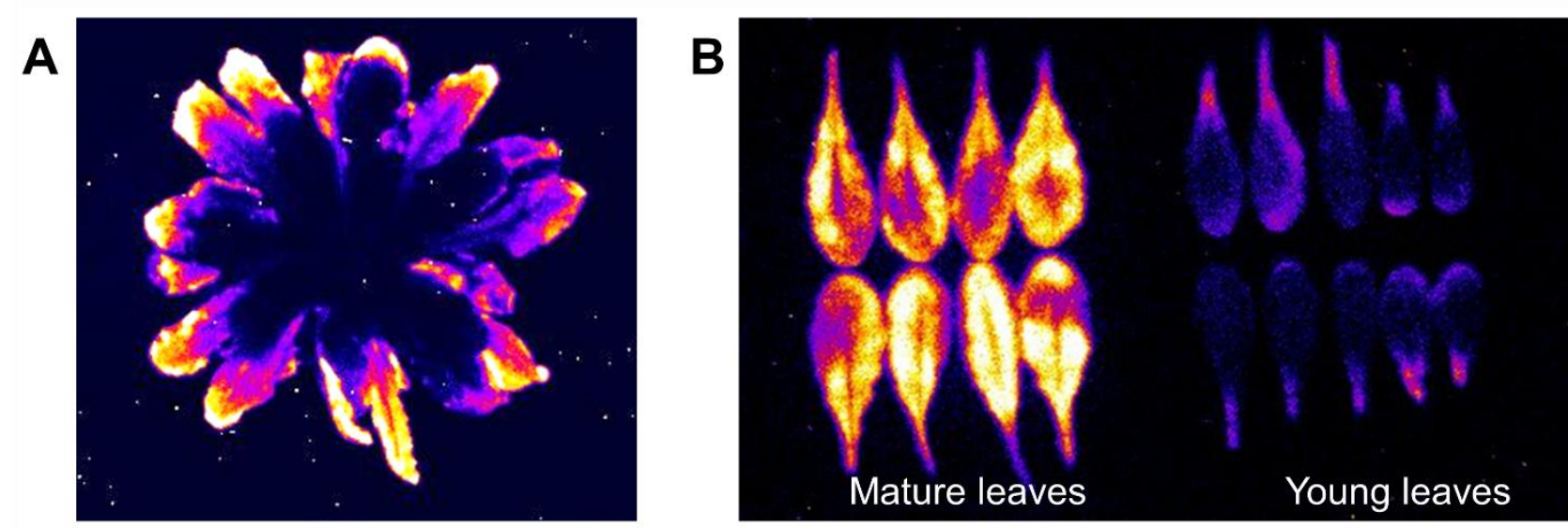

low

high

Figure 4. The extent of high light-induced lipid peroxidation is age dependent. A) Autoluminescence image of lipid peroxidation in an Arabidopsis plant exposed to high light $\left(1500 \mu \mathrm{mol}\right.$ photons $\mathrm{m}^{-2} \mathrm{~s}^{-}$ $\left.{ }^{1}\right)$ and low air temperature $\left(7^{\circ} \mathrm{C}\right)$, showing that lipid peroxides accumulate in old/mature leaves. $B$ ) Autoluminescence images of detached Arabidopsis leaves exposed to a PFD of $1100 \mu \mathrm{mol}$ photons $\mathrm{m}^{-2} \mathrm{~s}^{-1}$ for $16 \mathrm{~h}$ in a cold chamber $\left(6^{\circ} \mathrm{C}\right)$, confirming that young leaves are more tolerant to 

indicates signal intensity from low (blue) to high values (white).
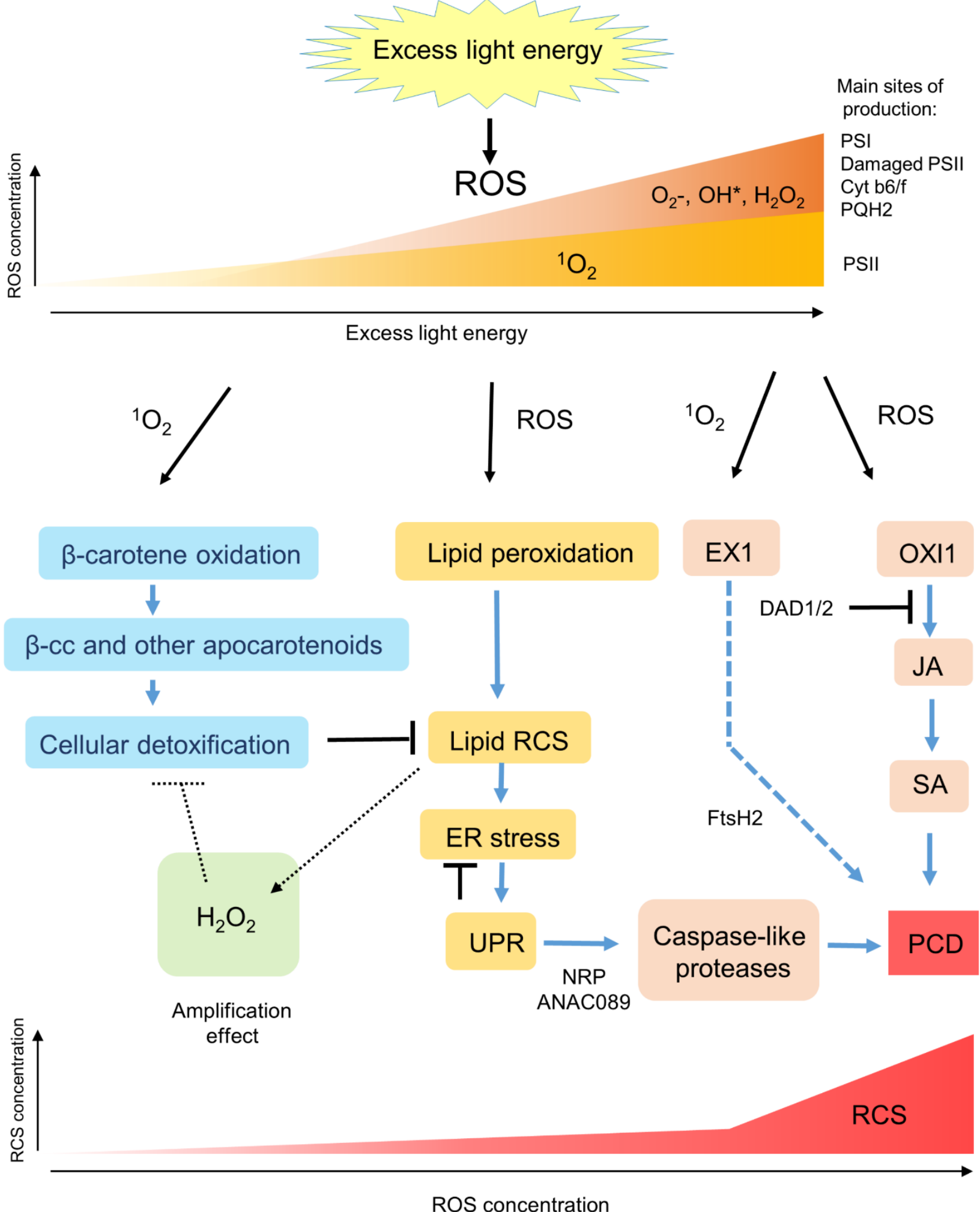

ROS concentration

802 Figure 5. Scheme of the pathways of excessive light induced PCD in plants. Excessive absorption of 803 light energy in the chloroplasts brings about ROS production that triggers several signaling pathways 804 leading to PCD. These pathways involve reactive products derived from lipid peroxidation, 
805 phytohormones and PCD-regulatory proteins. The ER plays an important integrative function in the 806 orientation of the stress response towards PCD. Apocarotenoids, such as $\beta$-cyclocitral, are upstream 807 signals that can induce cellular detoxification mechanisms modulating the pro-death action of toxic 808 lipid oxidation products.

809 